\title{
Accounting Issues: An Essay Series Part IX-Statement of Cash Flows
}

\author{
Judy Laux, Colorado College, USA
}

\begin{abstract}
The following article represents the last in a series dedicated to reinserting accounting theory into the introductory course. The current essay covers the theory associated with the Statement of Cash Flows along with articulation.
\end{abstract}

Keywords: Cash flows, accounting theory, articulation

\section{INTRODUCTION}

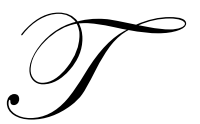

his essay series, beginning with Laux [2007a], defends the proposition that eliminating the theoretical chapter from the principles level accounting course has weakened the introduction for students new to this subject, perhaps resulting in some adverse selection for the accounting profession. As a remedy, it offers concise theoretical articles that apply some of the most important concepts from the hierarchy of accounting characteristics to the most basic accounting elements. In the series, the objective of decision usefulness and its associated components-relevance and reliability-have served as the cornerstones for investigating these accounting elements in a mountain hiking setting. [For a complete list of articles, please see the reference section of the current paper.] This final essay attempts to bring the various elements into focus by applying the foremost accounting characteristics, relevance and reliability, to the newest of the required financial statements, the Statement of Cash Flows. Studying this statement also represents an opportunity to discuss a concept integral to the accounting model-articulation. As with the previous works, sections are devoted to reviewing the mechanics, making the conceptual connections, addressing measurement issues, and presenting related literature.

\section{MECHANICS OF PREPARING THE STATEMENT OF CASH FLOWS}

Recall that the Statement of Cash Flows (SCF) requires separate sections depicting cash flows from three distinct sources: Operating, investing, and financing activities. Two approaches can be used to complete the operating activities section, the direct and indirect methods. The SCF chapter poses numerous challenges for most students, primarily because preparation of the first section requires a kind of "unlearning." The direct approach to generating cash flows from operating activities requires conversion of an accrual-based income statement to a cash flow basis using information from a comparative Balance Sheet. For example, the preparer must envision not just "Sales Revenue" (from the Income Statement) but "Cash Collected from Customers" (for the SCF) by investigating the change in Accounts Receivable during the period. In actuality, one can view the process as articulation in action. A firm's financial position at the beginning of the period (in this example, beginning Accounts Receivable, a "stock" owed to the firm by its customers at the start of the period) is changed by two "flows" during the period: "Sales" and "Collections." We can express this with the formula:
Accounts Receivable
$+\quad$ Sales
Collections
(SCF)
$=$ Accounts Receivable 2 (comparative BS)

The SCF simply shows the world the "Collections" figure when the direct method is used. We can solve for this figure as well by rearranging the equation: Collections $=$ Sales $+\mathrm{AR}_{1}-\mathrm{AR}_{2}$ or Sales plus any decrease in Accounts Receivable. As you can see, the analysis requires us to look at all three financial statements, the essence of articulation. 
By the time the newcomer has worked this type of analysis on all of the Income Statement figures, however, quite often mental burnout and/or confusion reigns! And then, to make matters worse, the indirect method is presented, whereby Net Income from the accrual-based Income Statement is converted to cash flows from operating activities by looking at changes in related Balance Sheet accounts. While the analysis of Accounts Receivable is similar, the thinking is reversed for a number of other accounting elements, ${ }^{1}$ again adding to the confusion and frustration.

The mechanics for preparing the other two sections of the SCF-Investing Activities and Financing Activities - are a bit more straightforward because they focus primarily on Balance Sheet changes. Exceptions include dealing with gains and losses on sale of assets, coupling accumulated depreciation with depreciation expense, and analyzing the change in Retained Earnings, which requires a look at that supporting statement. Still, in all cases, articulation can be a helpful concept, because the financial position (depicted on the Balance Sheet) is altered due to flows during the period (depicted on the Income Statement, Statement of Cash Flows, and Statement of Retained Earnings). Thus, every single balance sheet element can be analyzed formulaically ${ }^{2}$ with relevant information coming from all major financial statements. It can be difficult to see this beauty of the accounting model, however, when one is struggling simply to learn the mechanics!

So why does the accounting profession require companies to include a Statement of Cash Flows in their financial reporting? What does this statement offer decision makers that creates a more complete picture of a firm's financial well being? The next section addresses these questions as we put the SCF to the test of decision usefulness.

\section{THE STATEMENT OF CASH FLOWS AND ITS CONCEPTUAL CONNECTIONS}

Accountants are challenged on a daily basis to reflect the economic reality of business activities in their financial reports, and we are told early (and often) that accrual-based income provides the most defensible approach for reporting those events. Economic effort and expected changes in economic well being constitute the focal points for decision makers as they decide to invest in or lend to a company. But in the end, expected future cash flows, in the form of dividends to investors or interest and principal repayment to creditors, drive the ultimate investment or credit decision. So important is this cash flow aspect that the Financial Accounting Standards Board [1978, paragraph 39] states that a primary objective of financial reporting is to provide information to help investors, creditors, and others assess the amount and timing of prospective (future) cash flows. In addition to providing returns to investors and creditors, cash represents a kind of life line to sustain a company in the short-term as it maintains the liquidity necessary to pay its bills. This also lowers the overall risk of the firm, an effect that should keep stock prices higher, other things held equal. Thus, the SCF is relevant because accrual-based income, while a good measure of economic activity, does not highlight a firm's ability to generate cash flow. [See a good argument in defense of cash flow statistics in McEnroe, 1995.] In addition, the Income Statement does not address the longterm financing and investing decisions that affect solvency. While the expert analyst can glean some information about liquidity and solvency by inspecting a firm's comparative Balance Sheet, the SCF offers a much clearer picture of the sources and uses of cash; it is more understandable as a stand-alone statement for visualizing this economic aspect. Readers might also get a better idea of whether the sources of cash are sustainable over time.

How reliable is this information? Despite the "beauty" of the mechanics as described above (and in most principles-level texts), critics claim that accountants often go through a number of gyrations to produce the finished Statement of Cash Flows viewed by external users. The articulation so highly touted above evidently does not lend itself to close scrutiny. Bahnson, Miller, and Budge [1996] find that the articulation we expect does not exist in reality; $75 \%$ of over 9700 companies in their sample presented statements that did not articulate. Non-articulated

${ }^{1}$ Consider Accounts Payable. An increase would have been deducted from Cost of Goods Sold in arriving at "Cash Payments to Suppliers" under the direct approach but would be added to Net Income as a positive cash flow component under the indirect approach.

${ }^{2}$ For a fairly comprehensive set of equations, see the appendix to this article. 
changes in current accounts occur for a variety of reasons - changes in the reporting entity (such as acquisitions and divestitures), discontinued operations, extraordinary items, and the like can make reconciliation difficult. ${ }^{3}$ Many articulation problems could be avoided, however, through use of the direct method of reporting cash flows from operating activities. The profession levies a number of charges against the indirect method: It impairs transparency, limits usefulness, confuses analysts, and permits obfuscation. These very issues constitute fodder for much of the cash flow literature, covered in the following section.

\section{CASH FLOWS IN THE NEWS AND LITERATURE}

A wealth of literature related to cash flows exists, and this section will look at the best of these works from three perspectives. The first addresses the potential usefulness of information about cash flows; the second looks at perceived inadequacies, and the final portion looks at headlines directed at this topic.

Long before Statement of Financial Accounting Concepts No. 95 required the current Statement of Cash Flows the accounting profession questioned the potential usefulness of this type of information to investors and creditors. ${ }^{4}$ After the SCF became part of the financial reporting process, researchers swooped down on the opportunity to study the actual usefulness of this rather costly statement. Bowen, Burgstahler, and Daley [1987, p. 746] find that cash flow data offer incremental information content in addition to that contained in earnings and working capital from operations (the predecessor to cash flows) but that neither accrual-based nor cash-based information alone is as helpful as both together. ${ }^{5}$ Jordan, Waldron, and Clark [2007] discover that the sales figure predicts future cash flows better than either operating cash flows or earnings. Several studies look at the usefulness of cash flow data in credit analysis and bankruptcy prediction [Gahlon and Vigeland, 1988; Cornell and Apostolou, 1992; Ward, 1995], each finding the direct method of reporting cash flows from operating activities much more useful in those judgments. For Gahlon and Vigeland, a number of cash flow variables captured statistically significant differences between bankrupt and non-bankrupt firms, but these variables would not have been provided under the indirect cash flow approach. Carslaw and Mills [1991] also promote use of the direct method, claiming that an advantage of this approach is that it "permits an evaluation of cash flows relating to specific line items in the income statement such as gross sales, cost of goods sold or even total operating expenses" (p. 67). This idea (that disaggregating cash flows into subsets under the direct reporting method offers additional useful information) permeates a number of other studies.

Fairfield, Sweeney, and Yohn [1996] investigate the assertion that earnings disaggregation improves the predictive content of reported earnings: "For the average firm, there is incremental predictive content from disaggregating earnings into operating income ... non-operating income and income taxes, special items, and extraordinary items and discontinued operations" (p. 354). If such enhancement springs from breaking net income into its various components, why should cash flow information be any different? Barth, Cram, and Nelson discover in their 2001 investigation, "Accruals and the Prediction of Future Cash Flows":

As predicted, disaggregating accruals into major components - change in accounts receivable, change in accounts payable, change in inventory, depreciation, amortization, and other accruals-significantly enhances predictive ability... The cash flow and accrual components of current earnings have substantially more predictive ability for future cash flows than several lags of aggregate earnings. (p. 27)

${ }^{3}$ Hribar and Collins [2002] contend that this assumption of articulation "can lead to erroneously concluding that earnings management exists when no such opportunistic activity is present" (p. 106), potentially moderating the charge of unreliability. Many argue that lack of transparency is the real issue.

${ }^{4}$ For a brief overview of some of the studies directed at pre-SFAC 95 cash flow usefulness, see Bowen, Burgstahler, and Daley [1987, pp. 724-25 and 728].

${ }^{5}$ Kim and Kross [2005] find that "the relationship between current earnings and future operating cash flows has increased over time" and that "increasing accounting conservatism appears to play a role in this phenomenon" (p. 753). One could consider this as evidence refuting the need for cash flow data. However, most of the research supports the usefulness of non-accrual based supplemental information. 
Cheng and Hollie [2008] extend this 2001 study, examining the role of cash flow components in predicting future cash flows beyond the accrual components by looking at core and non-core cash flow components. They find that the core versus non-core distinction enhances the predictive ability of cash flow prediction models. Be aware, however, that many of these studies assume articulation in that accruals are measured as changes in balance sheet items. A sizeable body of literature argues that this is one of the major downfalls of the indirect method.

A number of empirical studies find fault with the Statement of Cash Flows, in particular the first section of that statement - cash flows from operating activities. Some of these are noted above [Gahlon and Vigeland, 1988; Cornell and Apostolou, 1992; Ward, 1995; Carslaw and Mills, 1991]. Barth, Cram, and Nelson [2001] disaggregate earnings expressly because the "aggregate earnings [figure] masks information contained in the individual components and . . . each major component of earnings reflects different or unique information about future cash flows" [Jordan, Waldron, and Clark, 2007, p. 54]. Thus predictability of future cash flows would be enhanced by requiring the direct method of reporting cash flows from operating activities. Not only would more information be provided, but nonarticulation would pose fewer problems. Economic reality would be better reflected, analysts would be better served, and transparency would be enhanced. Broome [2004] makes a good case as he poses the following (hard) questions:

Is the statement as useful to investors and creditors as it should be? Is it susceptible to manipulation by corporate managers? Can it and should it be improved? Would improvements in the statement increase investors' and creditors' confidence in financial accounting and reporting? (p. 16)

He contends that the complicated adjustments required under the indirect method are hard for the reader to understand and actually provide more leeway for manipulation. He advocates the direct method and asserts that any higher costs involved to produce the information in this way should be compared to the benefits investors would receive. He questions the transparency and reliability of current reporting, suggesting that many companies have inappropriately inflated cash flows from operations. Some instances are covered in the following paragraph devoted to news stories.

Finally, we look at some of the headlines with cash flow issues at their core. Cash flow reporting problems lie at the heart of a number of accounting debacles, including those at Adelphia, Dynegy, Qwest, Tyco, and WorldCom, as Broome describes in his 2004 article "Statement of Cash Flows: Time for Change!" For example, Tyco engaged in legal transactions but failed to reflect those events appropriately in the SCF, increasing their operating cash flows by categorizing outflows under investing activities but related inflows under operating activities [See White, 2002, and Maremont, 2002.]. Other cash flow related games are described in "Firm Acquired by Tyco Sped Payments to Bolster Cash Flow, E-Mail Indicates" [2002]. In both cases, the company failed to reflect the economic reality of the events, manipulating its cash flow reporting in the process. Similarly, Dynegy played with two sides of energy trades, treating inflows as revenues but outflows as investments rather than expenses [Sender 2002], and Qwest used network capacity to create the same fictitious cash flow picture [Day, 2002]. A favorite ploy is to shift operating cash outflows out of that first, very important, section of the SCF. Such was the case with both Adelphia and WorldCom, the first by capitalizing labor expenses (treating them as investments) and the latter using other operating expenses [Solomon, 2002]. In each of these cases, the companies used the indirect method of reporting cash flows from operating activities. Perhaps the accounting profession soon will hear the wake up call.

\section{THIS SERIES CONCLUDES}

This final essay concludes the review of theoretical concepts. Students and professors who have traveled this entire journey should now have an opinion on the value of such training at the introductory level. As author, I can only hope that your beliefs fall in line with my own - that there is real value in this conceptual coverage and that it makes the study of accounting more attractive because it delivers the message that keen minds are desperately needed to improve financial reporting.

Judith Laux is a Professor of Economics and Business at Colorado College, teaching and researching in the areas of accounting and finance. 


\section{REFERENCES}

1. Bahnson, Paul R.; Paul B. W. Miller, and Bruce P. Budge. 1996. "Nonarticulation in Cash Flow Statements and Implications for Education, Research, and Practice." Accounting Horizons, Vol. 10, No. 4: $1-15$.

2. Barth, Mary E.; Donald P. Cram, and Karen K. Nelson. 2001. "Accruals and the Prediction of Future Cash Flows." The Accounting Review. Vol. 76, No. 1: 27-58.

3. Bowen, Robert M.; David Burgstahler, and Lane A. Daley. 1987. "The Incremental Information Content of Accrual Versus Cash Flows." The Accounting Review. Vol. 62, No. 4: 723-47.

4. Broome, O. Whitfield. 2004. "Statement of Cash Flows: Time for Change!" Financial Analysts Journal. Vol. 60, Issue 2: 16-22.

5. Carslaw, Charles A. and John R. Mills. 1991. "Developing Ratios for Effective Cash Flow Statement Analysis." Journal of Accountancy. Vol. 172, No. 5: 63-70.

6. Cheng, C. and Dana Hollie. 2008. "Do Core and Non-Core Cash Flows from Operations Persist Differentially in Predicting Future Cash Flows?" Review of Quantitative Finance \& Accounting. Vol. 31, Issue 1: 29-53.

7. Cornell, David W. and Barbara Apostolou. 1992. "Direct Approach to Cash Flows Enhances Credit Analysis.” Business Credit. Vol. 94, April: 10-13.

8. Day, Kathleen. 2002. "SEC Targets 'Swap' Deals by Telecom Firms.” Washington Post. August 20: E1.

9. Fairfield, Patricia M.; Richard J. Sweeney, and Teri Lombardi Yohn. 1996. "Accounting Classification and the Predictive Content of Earnings." The Accounting Review. Vol. 71, No. 3: 337-355.

10. Financial Accounting Standards Board. 1987. "Statement of Cash Flows." Statement of Financial Accounting Standards No. 95. Stamford, Conn.

11. "Firm Acquired by Tyco Sped Payments to Bolster Cash Flow, E-Mail Indicates." 2002. Dow Jones Business News. March 18.

12. Gahlon, James M. and Robert L. Vigeland. 1988. "Early Warning Signs of Bankruptcy Using Cash Flow Analysis." The Journal of Commercial Bank Lending. Vol. 71, December: 4-15.

13. Hribar, Paul and Daniel W. Collins. 2002. "Errors in Estimating Accruals: Implications for Empirical Research." Journal of Accounting Research. Vol. 40, No. 1: 105-134.

14. Jordan, Charles E.; Marilyn A. Waldron, and Stanley J. Clark. 2007. "An Analysis of the Comparative Predictive Abilities of Operating Cash Flows, Earnings, and Sales." Journal of Applied Business Research. Vol. 23, Issue 3: 53-60.

15. Kim, Myungsun and William Kross. 2005. "The Ability of Earnings to Predict Future Operating Cash Flows Has Been Increasing —Not Decreasing.” Journal of Accounting Research. Vol. 43, No. 5: 753-780.

16. Laux, Judith A. 2007a. "Accounting Issues: An Essay Series Part I-Introduction to Accounting Theory and 'Cash."' Journal of College Teaching \& Learning. Vol. 4, No. 1: 61-65.

17. 2007b. "Accounting Issues: An Essay Series Part II-Accounts Receivable." Journal of College Teaching \& Learning. Vol. 4, No. 4: 1-6.

18. ___ 2007c. “Accounting Issues: An Essay Series Part III—Inventory.” Journal of College Teaching \& Learning. Vol. 4, No. 8: 1-6.

19. _ _ 2007d. "Accounting Issues: An Essay Series Part IV—Property, Plant, \& Equipment." Journal of College Teaching \& Learning. Vol. 4, No. 11, 41-46.

20. 2008e. "Accounting Issues: An Essay Series Part V_Intangible Assets." Journal of College Teaching \& Learning. Vol. 5, No. 1: 61-67.

21. _ 2008f. "Accounting Issues: An Essay Series Part VI—Investments in Securities." Journal of College Teaching \& Learning. Vol. 5, No. 6: 37-41.

22. 2008g. "Accounting Issues: An Essay Series Part VII—Liabilities." Journal of College Teaching \& Learning, forthcoming issue.

23. 2008h. “Accounting Issues: An Essay Series Part VIII—Stockholders' Equity.” Journal of College Teaching \& Learning, forthcoming issue.

24. Maremont, Mark. 2002. "How Is Tyco Accounting for Its Cash Flow?" Wall Street Journal. March 5: C1-2.

25. McEnroe, John E. 1995. “Cash Flow Accounting: Is it Time for Increased Disclosures?” Journal of Applied Business Research. Vol. 12, Issue 1: 47-52. 
26. Sender, Henry. 2002. "Cash Flow? It Isn’t Always What It Seems.” Wall Street Journal. May 8: C1, C3.

27. Solomon, Deborah. 2002. "Adelphia Overstated Cash Flow, Revenue over Past Two Years." Wall Street Journal. June 11: B5.

28. Ward, Terry. 1995. "Using Information from the Statement of Cash Flows to Predict Insolvency." Journal of Commercial Lending. Vol. 77, No. 7: 29-36.

29. White, Ben. 2002. "Tyco Report Paints Picture of Greed; Kozlowski Allegedly Decided Board." Washington Post, September 18: E1.

\section{APPENDIX}

The Mathematics of Articulation (Formulas for Describing Changes in the Accounting Elements)*

$\underline{\left(\mathrm{BS}_{1}\right)}$

\begin{tabular}{|c|c|c|c|c|c|}
\hline Accounts Receivable $_{1}$ & + & \multicolumn{2}{|l|}{$\begin{array}{l}\text { Sales } \\
\text { (IS) }\end{array}$} & $\begin{array}{l}\text { Collections } \\
\text { (SCF) }\end{array}$ & $=$ Accounts Receivable $_{2}$ \\
\hline $\begin{array}{l}\text { Prepaid Rent } \\
\text { (Insurance, etc.) }\end{array}$ & + & \multicolumn{2}{|c|}{$\begin{array}{l}\text { Cash Paid for Rent - } \\
\text { (SCF) }\end{array}$} & $\begin{array}{l}\text { Rent Expense } \\
\text { (IS) }\end{array}$ & $=$ Prepaid Rent $_{2}$ \\
\hline Interest Receivable $_{1}$ & + & \multicolumn{2}{|c|}{$\begin{array}{l}\text { Interest Revenue - } \\
\text { (IS) }\end{array}$} & \multicolumn{2}{|c|}{$\begin{array}{l}\text { Interest Collected }=\text { Interest Receivable } \\
(\mathrm{SCF})\end{array}$} \\
\hline Interest Payable $_{1}$ & + & \multicolumn{2}{|c|}{$\begin{array}{l}\text { Interest Expense - } \\
\text { (IS) }\end{array}$} & $\begin{array}{l}\text { Interest Paid } \\
\text { (SCF) }\end{array}$ & $=$ Interest Payable ${ }_{2}$ \\
\hline Salaries Payable $_{1}$ & + & \multicolumn{2}{|c|}{$\begin{array}{l}\text { Salaries Expense - } \\
\text { (IS) }\end{array}$} & $\begin{array}{l}\text { Salaries Paid } \\
\text { (SCF) }\end{array}$ & $=$ Salaries Payable $_{2}$ \\
\hline Unearned Revenues $_{1}$ & + & \multicolumn{2}{|c|}{$\begin{array}{l}\text { Cash Collected in } \\
\text { Advance } \\
\text { (SCF) }\end{array}$} & \multicolumn{2}{|c|}{$\begin{array}{l}\text { Revenues Earned = Unearned Revenues } \\
\text { (IS) }\end{array}$} \\
\hline Dividends Payable $_{1}$ & + & \multicolumn{2}{|c|}{$\begin{array}{l}\text { Dividends Declared - } \\
\text { (Statement of RE) }\end{array}$} & $\begin{array}{l}\text { Dividends Paic } \\
\text { (SCF) }\end{array}$ & $=$ Dividends Payable $_{2}$ \\
\hline Bonds Payable $_{1}$ & + & $\begin{array}{l}\text { Bonds Issued } \\
\text { (SCF) }\end{array}$ & - & $\begin{array}{l}\text { Bonds Retired } \\
\text { (SCF) }\end{array}$ & $=$ Bonds Payable $_{2}$ \\
\hline Common Stock $_{1}$ & + & $\begin{array}{l}\text { Stock Issued } \\
\text { (SCF) }\end{array}$ & - & $\begin{array}{l}\text { Stock Retired } \\
\text { (SCF) }\end{array}$ & $=$ Common Stock $_{2}$ \\
\hline Treasury Stock ${ }_{1}$ & + & $\begin{array}{l}\text { Treasury Stock } \\
\text { Repurchased } \\
\text { (SCF) }\end{array}$ & - & $\begin{array}{l}\text { Treasury Stock } \\
\text { Reissued } \\
\text { (SCF) }\end{array}$ & $=$ Treasury Stock 2 \\
\hline Retained Earnings $_{1}$ & + & $\begin{array}{l}\text { Net Income } \\
\text { (IS) }\end{array}$ & - & $\begin{array}{l}\text { Dividends Dec } \\
\text { (Statement of } \mathrm{F}\end{array}$ & red $=$ Retained Earnings $s_{2}$ \\
\hline
\end{tabular}

Notice that analysis of a few items can be a bit more complex. For example, consider Inventory (which can be purchased on Accounts Payable). The related IS account is Cost of Goods Sold. (A perpetual system is assumed.) 


$\begin{array}{llll}\text { Inventory }_{1} & + & \begin{array}{l}\text { Purchases on Account }- \\ \text { (See Accounts Payable) }\end{array} & \begin{array}{l}\text { COGS } \\ (\text { IS })\end{array} \\ \text { Accounts Payable }_{1} & + & \text { Purchases on Account }- \text { Inventory }_{2} \\ & \begin{array}{l}\text { Payments on Account = Accounts Payable } \\ (\text { SCF })\end{array}\end{array}$

Thus for the SCF analysis of "Cash Payments to Suppliers," we can use the formula:

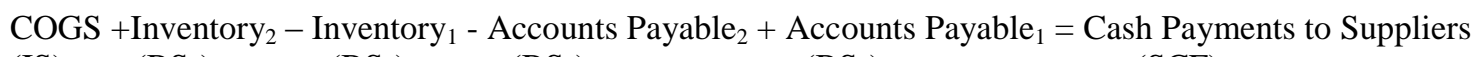
(IS)
$\left(\mathrm{BS}_{2}\right)$
$\left(\mathrm{BS}_{1}\right) \quad\left(\mathrm{BS}_{2}\right)$
$\left(\mathrm{BS}_{1}\right)$
(SCF)

Similarly, the analysis of equipment (and its associated accumulated depreciation account) can be tricky:

Equipment $_{1}+$ Purchases of Equipment - Sales of Equipment $=$ Equipment $_{2} \quad$ and

Acc. Deprec. ${ }_{1}+$ Deprec. Expense - Depreciation Associated with Eqpt. Sold= Accumulated Depreciation 2

Gains and losses can occur that would appear on the IS, and we don't always know the cash flow consequences unless we investigate the accounts. Exchange transactions can also require special sleuthing, but these few exceptions do not negate the usefulness of viewing articulation through the formulas above.

*The sources of the information are as follows: For the first and last item in each formula, the beginning and endof-the-year Balance Sheets, respectively. For other items: "IS" = Income Statement and "SCF" = Statement of Cash Flows. "Statement of RE" is the Statement of Retained Earnings. 


\section{NOTES}

